УДК 347.779

DOI https://doi.org/10.32837/apdp.v0i88.3052

С. А. Булат, Р. С. Пічко

\title{
АКТУАЛЬНІ АСПЕКТИ ПОДАЛЬШОЇ ПРАВОВОЇ ОХОРОНИ НАУКОВОГО ВІДКРИТТЯ В КОНТЕКСТІ СУЧАСНОГО ЗАРУБІЖНОГО ДОСВІДУ
}

Постановка проблеми. Інтеграція України в міжнародний науково-дослідницький простір є одним із вихідних завдань її подальшого успішного інноваційного розвитку. А в контексті необхідності наближення й уніфікації норм вітчизняного законодавства у сфері інтелектуальної власності до норм і стандартів як Європейського Союзу, так і інших закордонних країн зумовлює переоцінку досвіду і знань, пов'язаних із комерціалізацією інновацій на світовому рівні, вимагає застосування нових підходів до врегулювання їх на законодавчому рівні. Одним із таких інноваційних об'єктів, до якого нині привернута увага з боку держави і суспільства, $\epsilon$ наукове відкриття.

Аналіз останніх досліджень і публікацій. Визначення наукового відкриття, його правового режиму і деякі аспекти його правової охорони досліджувались у наукових працях Г.О. Андрощука, Ю.М. Капіци, О.П. Сєргєєва, В.В. Потоцького, Є.А. Кожиної, Ф.К. Клименко, А.М. Павлова, В.І. Серебровського й інших. Водночас на сучасному етапі питання найбільш доцільного напряму подальшої правової охорони наукового відкриття залишається невисвітленим.

Мета статті. Автори цієї статті мають на меті не тільки визначити правові риси, які властиві науковому відкриттю як об'єкту інтелектуальної власності, але також проаналізувати основні правові підходи до визначення правового режиму наукового відкриття в Україні і за кордоном, запропонувати найбільш доцільний, на їхній погляд, напрям подальшої правової охорони наукового відкриття, з урахуванням вітчизняного і закордонного досвіду в цій сфері.

Виклад основного матеріалу. Якщо ми звернемось до п. VIII ст. 2 Стокгольмській дипломатичній конвенції, що заснувала Всесвітню організацію інтелектуальної власності в 1967 р., ми побачимо, що на міжнародному нормативному рівні поняття «наукового відкриття» було закріплено серед інших об'єктів інтелектуальної власності, які отримали своє подальше законодавче регулювання. Конвенцією визнавалися всі права на результати інтелектуальної діяльності, зокрема й наукові відкриття, інші, які належать, серед іншого, до інтелектуальної діяльності у виробничій і науковій галузях [1].

Свого часу закордонним дослідником О.П. Сергєєвим було запропоновано для наукового відкриття і ще низки декількох об’єктів інтелектуальної власності термін «нетрадиційні» через відсутність належного законодавчого регулювання і відмінності їх від об'єктів авторського права [2, с. 30]. Однак усе різноманіття результатів творчої діяльності не обмежується лише творами науки, літератури, мистецтва. Крім вищезазначених об'єктів, які створюються завдяки творчій, інтелектуальній діяльності людей і є цінністю для суспільства, існують й інші об'єкти, 
які також потребують суспільного визнання і правової охорони. На сучасному етапі інновацій їх існування і необхідність правового регулювання пов'язаних із ними суспільних відносин визнається більшістю розвинених закордонних держав [2, с. 30]. Саме такі об'єкти інтелектуальної власності, до яких належить і наукове відкриття, є основою для розвитку нових наукоємних технологій, сприяють розвитку й удосконаленню науково-технічних, інноваційних здобутків.

Ст. 457 Цивільного кодексу України визначено, що науковим відкриттям визнається встановлення невідомих раніше, таких, що об'єктивно існують, закономірностей, властивостей і явищ матеріального світу, які вносять докорінні зміни в рівень наукового пізнання. Цивільний кодекс України визначив наукове відкриття як об'єкт, який потребує належного визнання і надійної правової охорони. Зокрема, його гл. 38 має назву «Право інтелектуальної власності на наукове відкриття». Огляд цієї глави доводить, що законодавець присвятив праву на наукове відкриття дві статті і зазначив, що відносини, які виникають стосовно права на наукове відкриття, мають охоронятися в порядку, встановленому відповідним законом [3].

3 огляду на правову природу наукового відкриття, йому як об'єкту інтелектуальної власності властиві такі риси:

- наукове відкриття це результат творчої, інтелектуальної, науково-пізнавальної діяльності;

- наукове відкриття має відрізнятись новизною отриманих результатів і мати вираження в об'єктивній формі;

- науковий, фундаментальний результат має полягати саме у встановленні і виявленні не відомих раніше об'єктивних закономірностей, властивостей або явищ матеріального світу;

- наукове відкриття має бути відповідним чином пояснено [4, с. 9].

Правовими ознаками наукового відкриття виступають вірогідність, новизна і фундаментальність. Але визначення наукового відкриття було б неповним без розкриття сутності об'єктів, які його характеризують. Зміст поняття відкриття розкривається саме через три його об’єкти: явище, властивість і закономірність.

Ретроспективний аналіз питання правової охорони наукових відкриттів свідчить про те, що в 1947 р. було розпочато державну реєстрацію наукових відкриттів у Радянському Союзі. Це було пов'язано з умовами, у яких опинився Радянський Союз після війни, зокрема з нагальною необхідністю відновлення всіх сфер його життєдіяльності, а також зростанням ролі науки що, у свою чергу, зумовило високе зростання зареєстрованих наукових відкриттів. Ухвалення в цей період цілої низки нормативних документів зробило інститут реєстрації наукового відкриття практично завершеною конструкцією права від прийняття заявок на наукові відкриття, проведення наукової експертизи, реєстрації і до видачі дипломів на них. Існування радянського інституту реєстрації наукових відкриттів також стало фундаментальною основою для проведення подальших наукових досліджень [5, с. 30].

Сучасний розвиток законодавства у сфері інтелектуальної власності, зокрема щодо правової охорони наукових відкриттів в Україні, свідчить про спроби законодавчого врегулювання питання правової охорони наукових відкриттів. Так, у 2004 р. було підготовлено проєкт закону України «Про охорону прав на наукові 
відкриття», який пройшов перше читання і готувався до другого. Цим законопроєктом були визначені права авторів наукових відкриттів, порядок здійснення експертизи наукових відкриттів, визначення пріоритету, видачі дипломів тощо. З об’єктивних причин цей закон не набув чинності [6]. Згодом, у 2010 р., на Міжпарламентській асамблеї країн - учасниць Співдружності Незалежних Держав було ухвалено Модельний закон «Про охорону прав на наукові відкриття». Цим Законом регулюються ключові питання правової охорони наукових відкриттів. Закон має рекомендований характер для інших країн, у яких можуть бути впроваджені державна реєстрація й охорона наукових відкриттів [7].

За кордоном питання правової охорони наукових відкриттів регулювалося по-різному. Так, бралися до уваги судові рішення із ключових питань, пов'язаних із розмежуванням відкриття і винаходу. Наприклад, Високим судом Австралії у справі Національної корпорації з розвитку досліджень проти уповноваженого 3 патентів (1959 p.), 102 CLR 252, (1961) RPC 134, визначалося, що «істина полягає в тому, що різниця між винаходом і відкриттям є недостатньо точною, що вводить в оману в цій галузі обговорення. Справді, може бути відкриття без винаходу або через те, що відкриття являє собою якусь абстрактну інформацію без натяку на практичне застосування його з корисною ціллю, або тому, що його застосування перебуває поза галуззю виробництва» [8].

Водночас стрімке економічне зростання, розвиток інноваційних технологій і виробництва зумовили в подальшому перегляд поглядів закордонних учених на необхідність удосконалення правової охорони наукових відкриттів.

Між науковим відкриттям і винаходом не робилося принципової різниці, що підтверджувалося думкою багатьох дослідників і правників. Так, наприклад, на думку канадського вченого Майка Фенвика, « <...> не варто розкривати сутності важливих відкриттів (винаходів) до того, як буде ухвалено рішення про їх захист (патентом) <...> такий крок може сприяти розвитку культури інновацій» [9].

На думку американських правників, «<...> наукові відкриття, які набувають все більш економічного значення, також стикаються із труднощами, коли йдеться про захист, оскільки патентні системи традиційно відмовляють у захисті таких відкриттів. Навітьбільше, університетиідослідницькіустанови, уякихпроводятьсяфундаментальні наукові дослідження, традиційно приділяють увагу ранньому розповсюдженню результатів, що також суперечить вимогам отримання патентів, оскільки, наприклад, у багатьох країнах будь-яке розкриття винаходу до подання заявки на патент перешкоджає патентоздатності» $[10$, с. 6]. Відомий випадок, коли у Сполучених Штатах Америки був виданий патент Коена-Бойера на основну методику рекомбінатної ДНК, але відкриттю було відмовлено в захисті в Європі через ранню публікацію матеріалів заявки і подальшу втрату матеріальної винагороди [11, с. 29, 30].

Нині за кордоном не вщухають спори стосовно можливості охорони відкриттів у галузі біотехнологічної індустрії. Так, зокрема, деякі сінгапурські вчені вважають, що нечітка різниця між відкриттям і винаходом, особливо в галузі відкриття генів заважає належному розумінню щодо обрання способу їх охорони, оскільки, на їхню думку, генетична інформація є частиною природи, тому не підлягає патентуванню [12]. 
Отже, як свідчить проведений огляд, існують різні погляди на спосіб правової охорони наукових відкриттів як в Україні, так і за кордоном. Водночас стрімкий розвиток галузі інтелектуальної власності, поява нових результатів, об'єктів, технологій та інновацій, зокрема і наукових відкриттів, зумовлюють нині пошук найбільш доцільного напряму їх подальшої правової охорони.

Висновки. У науковому відкритті, окрім фундаментальної частини, існує також і практична частина, яка містить охороноздатні технічні (технологічні) рішення, які можуть бути визнані винаходами і корисними моделями. Саме ця практична частина наукового відкриття містить матеріали, які доцільно виявляти й охороняти залежно від того, яку мету мають автори (винахідники) потенційних винаходів і корисних моделей для відповідної охорони матеріалів заявки наукового відкриття і винаходу. У цьому разі з'являється можливість розпорядитися майновими правами інтелектуальної власності на такі об'єкти, отримати охоронний документ на них у державній установі.

\section{Jimepamypa}

1. Convention Establishing the World Intellectual Property Organization. URL: http://zakon2.rada.gov.ua/laws/show/995_169.

2. Сергеев А.П. Право интеллектуальной собственности : учебник. 2-е изд., перераб. и доп. Москва : ТК «Велби-Проспект», 2004. 752 с.

3. Цивільний кодекс України : Текст відповідає офіц. Київ : Школа, 2003. 384 с.

4. Булат Є.А. Наукове відкриття - об’єкт цивільних правовідносин : монографія. Дніпропетровськ : Герда, 2013. $124 \mathrm{c}$.

5. Научные открытия учёных Украины (Андрощук Г.А., Бошицкий Ю.Л., Булат Е.А. и др.) ; Ин-т гос-ва и права им. Корецкого НАН Украины ; Междунар. центр прав. проблем инт. собственности ; Междунар. ассоциация авторов науч. открытий. Киев : Новая идеология, 2004. 112 с.

6. Про охорону прав на наукові відкриття : проєкт закону України від 14 грудня 2004 р. № 6414. URL: http://zakon.rada.gov.ua.

7. Модельный закон об охране прав на научные открытия: Закон Межпарламентской Ассамблеи государств-участников СНГ от 7 апреля 2010 г. № 349. URL: http://zakon3.rada.gov.ua/laws/ show/997_m98/page.

8. Discoveries, Ideas, Scientific Theories, Schemes and Plans. URL: http://manuals.ipaustralia.gov.au/ patents/national/patentable/2.9.2.5_discoveries_ideas_scientific_theories_schemes_and_plans.htm.

9. Fenwick Mike. Scientists need to protect their discoveries with patents. URL: https://www.cheminst.ca/magazine/article/scientists-need-to-protect-their-discoveries-with-patents/.

10. The Global Dimensions of Intellectual Property Rights in Science and Technology [Mitchel B. Wallerstein, Mary E. Mogee, Robin A. Schoen] ; National Research Council, Policy and Global Affairs, Office of International Affairs. Washington DC : The National Academies Press, 1993. 450 p.

11. Benko Robert. Protecting Intellectual Property Rights : Issues and Controversies. Washington DC : American Enterprise Institute, 1987.60 p.

12. Thian Alex. Protection of Biotech Intellectual Property Rights : A Singapore Perspective. URL: https://www.sciencemag.org/careers/2001/10/protection-biotech-intellectual-property-rightssingapore-perspective. 


\section{Анотація}

Булат $\boldsymbol{C}$. А., Пічко Р. С. Актуальні аспекти подальшої правової охорони наукового відкриття в контексті сучасного зарубіжного досвіду. - Стаття.

У статті надано характеристику наукового відкриття як об’єкта інтелектуальної власності, висвітлено його особливу правову природу. Визначено, що правовими ознаками наукового відкриття виступають вірогідність, новизна і фундаментальність, а зміст поняття «відкриття» розкривається через такі його об'єкти, як явище, властивість і закономірність. Відзначено необхідність подальшого правового регулювання суспільних відносин, пов'язаних із науковими відкриттями, оскільки вони є основою для розвитку нових наукоємних технологій, сприяють розвитку й удосконаленню науково-технічних, інноваційних здобутків.

Підкреслено, що за часів радянського періоду інститут реєстрації наукового відкриття став практично завершеною конструкцією права, що дозволило не тільки визнати наукові досягнення на державному рівні, але також створити базу для проведення подальших фундаментальних досліджень. Наголошено, що на сучасному етапі розвитку законодавства у сфері інтелектуальної власності були здійснені кроки в напрямі вдосконалення правової охорони наукових відкриттів через ухвалення проєкту закону України «Про охорону прав на наукові відкриття» і Модельного закону «Про охорону прав на наукові відкриття» країн - учасниць Співдружності Незалежних Держав. Відзначено, що на сучасному етапі в деяких закордонних країнах у контексті правової охорони між науковим відкриттям і винаходом не робиться принципової різниці і як охоронний документ видається патент. Розглянуто питання охорони відкриттів у сфері біотехнологічної індустрії.

У контексті європейського досвіду, а також досвіду, набутого іншими іноземними країнами, запропоновано виявляти із практичної частини наукового відкриття технічні (технологічні) рішення, які підлягають патентуванню, з можливістю отримання охоронних документів на них.

Ключові слова: наукове відкриття, правова охорона, інновації, винахід, удосконалення законодавства, технологічні рішення.

\section{Summary}

Bulat Ye. A., Pichko R. S. Topical aspects of the further legal protection of scientific discovery in the context of modern foreign experience. - Article.

The article describes characteristics of scientific discovery as an object of intellectual property and highlights its special legal nature. It is found that the legal features of a scientific discovery include probability, novelty and fundamentality, and the content of the concept of discovery is revealed through its objects such as phenomenon, property and regularity. The necessity of the further legal regulation of public relations related to scientific discoveries had been established, because they serve as the basis for the development of new science-intensive technologies and promote the development and improvement of scientific, technical and innovative achievements.

It is emphasized that during the Soviet period the institute of registration of scientific discovery became almost a complete construction of law, which allowed not only to consolidate outstanding scientific achievements at the country level, but also to lay the groundwork for further fundamental research. It is highlighted that that at the present stage of development of legislation in the field of intellectual property the steps have been taken to improve the legal protection of scientific discoveries through the adoption of the draft law of Ukraine "On the protection of rights to scientific discoveries" and model law "On the protection of rights to scientific discoveries" in the CIS countries. It is noted that at the present stage in some foreign countries there is no fundamental difference between a scientific discovery and an invention in the context of legal protection, and a patent is issued as a protection documents. Special attention is paid to the possibility of protection of discoveries in the field of biotechnological industry. The issue of discovery protection in the field of biotechnology industry is considered.

In the context of European experience, as well as an experience gained by other foreign countries, it is proposed to identify from the practical part of the scientific discovery the technical (technological) solutions subject to patenting with the possibility of obtaining of the relevant protection documents.

Key words: scientific discovery, legal protection, innovations, invention, improvement of legislation, technological solutions. 